\title{
The Mediating Effects of Duty Orientation on the Relationship between Perceived Organizational Support and Organizational Citizenship Behavior in the Public Banks of Egypt
}

\author{
Mostafa Mohamed Ahmed AlKerdawy ${ }^{1}$ \\ ${ }^{1}$ Department of Business Administration, Damietta University, Faculty of Commerce, Egypt \\ Correspondence: Mostafa Mohamed Ahmed AlKerdawy, Associate Professor, Faculty of Commerce, \\ Department of Business Administration, Damietta University, New Damietta, P.O. Box 34519, Egypt. E-mail: \\ mostafa_alkerdawy@yahoo.com
}

Received: April 24, 2014

Accepted: June 13, 2014

Online Published: July 25, 2014

doi:10.5539/ijbm.v9n8p155

URL: http://dx.doi.org/10.5539/ijbm.v9n8p155

\begin{abstract}
Organizational citizenship behavior is a key aspect of employees' discretionary behavior, and is very crucial in bank activities. This study aims to examine the impact of perceived organizational support (POS) on organizational citizenship behavior (OCB) through mediating duty orientation (DO). Survey data from 403 employees in public banks indicated that DO play partial mediating role in the relationship between POS and OCB. Moreover, POS has positive and significant influence on both DO and OCB; DO also has positively influenced on OCB. In the light of findings, the study discussed number of theoretical and managerial implications.
\end{abstract}

Keywords: perceived organizational support, duty orientation, organizational citizenship behavior

\section{Introduction}

Contemporary and changing business environment makes it imperative for the banks to keep their managerial techniques concurrent with the current challenges. Adopting new managerial approach has therefore become urgent need for the banks to meet the demands of their customers and competitive banking environment. Employees play critical role in achieving goals of banks, they perform as a team work and cooperate equally towards the realization of a common goal. Each organization needs to be able to adapt with changing situations, this will be achieved only when it possess the staff willing to participate in the successful organizational changes without the need for the job's formal requirements which called OCB. Although such behaviors go beyond the formal expectations, but they are very crucial for the existence of any organization (Khani et al., 2013).

In today's turbulent global economy, any organizations expect from its members to not only fulfil their formal activities, but also initiate to help their colleagues. Therefore, many researchers are directing great interest on employees' affirmative behaviors such as OCB (Yen \& Teng, 2013). By the entrance of private financial institutes to the market, banks and financial service providers have gained special importance regarding service provision quality; they need committed and hardworking staff to achieve its goals (Saufi et al., 2013). So, employees in the bank should be encouraged to behaviors that exceeds over their regular duties such as solving clients' problems and serve bank and its customers favorably. Therefore, motivating employees to exhibit OCB and realizing what factors have impact on their OCB are attractive research interests for many researchers and practitioners.

For many decades, researchers and the public have become increasingly concerned about unethical organizational behavior and how organizations and their members get themselves into and, more importantly, stay out of trouble. Behavioral ethics' researchers have studied a variety of essential organizational context factors that have been shown to prevent unethical conduct (Trevino et al., 2014). In addition, considering individuals as autonomous moral actors is incomplete; because this neglects individuals' orientations toward their moral duties and obligations to their groups (Hannah et al., 2014; Folger et al., 2013). So, this study tries to inspirit the concept of "the psychology of obligation" as an explanatory framework for ethical behavior at work. According to this standpoint, employees act on the basis of responsibilities, obligations, and group moral imperatives that replace their self-interest. While scholars acknowledge that a greater understanding of duty 
orientation in organizations is needed, there is a paucity of theoretical development in this regard, and to our knowledge there is a little empirical work in this direction. In doing so, this study seeks to encourage inquiry into the antecedents of duty like POS and how it influences ethical thoughts and behaviors like OCB.

This study suggests that a focus on duty orientation contributes to the understanding of behavioral ethics at organizational settings in fourth ways. First, obligation toward duties plays an important role in moral functioning that has been relatively neglected in modern and postmodern theories of psychology and organizational behavior (Hannah et al., 2014). Second, this study suggests that DO can improve our understanding of the mechanisms through which POS affects behavior in organizations as general and banks especially. Third, an individual first considers whether he or she has a personal moral responsibility to act. Thus, a personal sense of duty promotes moral agency. If an individual is highly driven by moral obligations and duties, there may in some cases be no ethical judgment to be made, only a personally felt necessity to fulfill one's duty (Wren, 2010). Fourth, this study believes that investigating DO and its effects on OCB will aid scholars in predicting aspects of ethical behavior throughout organization that extend beyond minimal compliance.

\section{Literature Review and Hypothesis Development}

\subsection{Relationship between POS and DO}

Although POS Has received little attention and study until the mid-1990's, it has grown rapidly in the last few years. Many of the findings of previous studies concluded to the presence of strong and positive effect between POS and job outcomes such as job satisfaction and organizational commitment (Nitesh et al., 2013; Bowra \& Naeem, 2013; Hakkak \& Ghodsi, 2013; Ghasemizad \& Mohammad khani, 2013; Alijanpour et al., 2013). Whenever, Moon et al. (2013) demonstrated that employees are encouraged to modify their inner feeling to meet organizationally desired emotions when they have high level of POS.

There is considerable empirical support for the notion that POS has influence on many outcomes favourable to employees like job satisfaction and their organization such as reduced turnover and lessened withdrawal behavior (Rhoades \& Eisenberger, 2002). Islam et al. (2013) showed that when employees enjoy with high level of POS, they reciprocate it by showing more commitment and changing their intentions to leave the organization. So, the organization should consider employees' opinions while making decisions, this will not only encourage them to change their behaviors but also enhance their working capacity which ultimately influence on organizational effectiveness. So, this study argues that when individual perceive high level of POS from organization, they will be committed ethically to do their duties beyond normal standards of work through duty orientation.

Although there is a limited research about relationship between POS and DO, but Biswas \& Bhatnagar (2013) suggested that when employees perceive high levels of organizational support, they will psychologically encouraged toward exerting considerably higher levels of effort throughout organization. Hannah et al. (2014) define duty orientation as "an individual's volitional orientation to loyally serve and faithfully support other members of the group, to strive and sacrifice to accomplish the tasks and missions". From this viewpoint, this study suggests that individual with a high duty orientation will tend to think about and make judgments on ethical issues through the lens of their duties toward their organization, and they will have greater volition to behave in a manner that is consistent with those duties and to honor its codes and principles. According to this definition, duty orientation involves three dimensions (Hannah et al., 2014):

1) Duty to Member, which reflects a willingness to be faithful to and serve one's group and its members and to put the interests of others ahead of one's own interests;

2) Duty to Mission, which means a commitment to accomplish the missions and objectives of the group, including a willingness to exert effort, accept personal sacrifices or risk or loss, and otherwise strive to support the accomplishment of the group's tasks and missions;

3) Duty to Codes, which reflects in a constant obligation to demonstrate integrity and to act honorably, doing what is right according to the customs of specific group.

DO concerns with what individuals believe they owe to their group and organization in terms of loyal service and fidelity to the group's members, mission and tasks of their organization, and its moral codes. In ethical theory, an individual's deep understanding and appreciation of the customs of the community and his or her expectations related to those norms is similar to what called "good will," which is the foundation of a sense of duty (Sherman, 1997). With high DO, one's obligations to his organization carry personal moral significance, they are authoritative, and they obligate one to certain kinds of conduct that add stability to and support the welfare of the organization (Wren, 2010). Accordingly, when employees perceive high level of POS; they will be more DO by loyally serve and faithfully support other members of their group in organization; strive and 
sacrifice to accomplish the tasks and missions that organization faces; and honor the codes and principles of it. So, this study expects that employees in the public banks who have high level of POS will be more DO. Thus, the first hypothesis is formulated as follows:

Hypothesis 1: Public Banks' employees' POS positively influences on DO.

\subsection{Relationship between $P O S$ and $O C B$}

Theoretically, employees who have a high level of POS should make the utmost of their effort to improve their work performance and engaging more readily in OCB, because it is beneficial to their organizations (Shen et al., 2013). However, one of the new constructs which has attracted attention of authorities is OCB which is defined as "individual behaviors that are discretionary and not formal rewarded directly by the organization" (Organ 1988, p. 4). According to social exchange theory, employees reciprocate extra OCB to achieve a good reputation for their organization, when they perceive that it gives a particular care to their values and interests (Chiang \& Hsieh, 2012). There is no general consensus on dimensions of the OCB, but applicable classification of OCB has been presented by Organ (1988) in the following five dimensions:

- Altruism: which is defined as a group of discretionary behaviors directed to support co-workers resolving their problems;

- Conscientiousness: means also a group of discretionary behaviors that enable the organization to go beyond the minimum role requirements through hard work;

- Sportsmanship: defined as the willingness of the employee to tolerate with, imperfect situations without complaint;

- Courtesy: includes a group of discretionary behaviors that aimed to prevent work-related problems with co-workers from occurring;

- Civic virtue: involves behaviors that make employees remaining mindful and initiative when participating in organizational activities.

In his study on the impact of POS on OCB, Wayne et al. (1997) demonstrated that POS is a strong predictor of employees' OCB. So, increased POS improves employees' performance and their willingness to stay in the organization on one hand, and reduces job pressures and feedback behaviors such as willingness to leave the work and deviant behaviors on the other hand (Shusha, 2013; Farasat \& Ziaaddini, 2013). Thus, organizations should support and create an appropriate climate in which employees are able to talk, because if employees are not allowed to express their opinions and ideas related to work, their OCB level will decrease and the organization will lose new ideas; thoughts; creative solutions and employees' efforts that exceeds usual job duties which might be very beneficial to the organization (Çinar et al., 2013). Lastly, Beheshtifar et al. (2012) suggested that organizational support are important to employees' perceptions of the quality of their exchange relationships with their organizations, which influence on employees' work attitudes and behaviors indirectly. Based on existing literature, we conclude that POS positively influence on OCB, Thus, the second hypothesis is formulated as follows:

Hypothesis 2: Public Banks' employees' POS positively influences on OCB.

\subsection{Relationship between $D O$ and $O C B$}

Most of the human resource practices in contemporary organizations are humanistic and ethical in its nature and are concerned with behavioral aspects of employees. According to existing literature, DO considers one of the most variables which have positive and significant effect on OCB (Hannah et al., 2014). DO plays an important role in promoting OCB; where Duty to members in organization promotes pro-group behaviors such as spending more time in training or mentoring coworkers, and diminishes group-limiting behaviors such as antisocial acts directed against coworkers or speaking negatively about the group or organization to outsiders. At higher levels of support, DO may promote virtuous behaviors such as benevolence personal vacation days to an ill coworker or avoiding unethical behaviors such as disclosing proprietary information with competitor organizations.

Hannah et al. (2014) suggests that duty to mission represents an individual's volitional orientation to support the mission, tasks, or purposes of the group and organization. Any organization exists for a reason and has a mission that serves some valued end or purpose. Duty to mission involves more that minimal efforts to contribute to accomplishing the mission of organization. The duty of care demands that employees invest at least a minimally acceptable amount of time and effort and exercise a sufficient level of skill in organization (Scott, 1983). Organizations frequently operate in complex environments characterized by ambiguity, volatility, and risk. So, achieving success in accomplishing tasks and missions in such contexts requires that leaders and group members 
alike are oriented to take responsibility and initiative that goes beyond minimum standards required by a duty of care. Higher levels of duty to mission are represented by personal resolve to do whatever may be required to avoid the failure of tasks and missions and to make personal sacrifices and accept personal risks to ensure the success of an organization's performance goals. High DO thus not only promotes task accomplishment, it may also reduce the likelihood that an individual will engage in what Tyler and Blader (2000) described as "group limiting behaviors' such as withholding information or social loafing (p. 27).

Duty to codes defined as a constant adherence to the normative codes and customs associated with the group and organization. These codes are seldom written into a formal set of rules, but it commits organization's members to high ethical standards. These codes define not only how members should interact with one another, but also how they should interact with others outside of the group. They set boundaries for behavior and distinguish honorable acts from shameful ones (March \& Weil, 2005). Duty to codes is closely associated with the notion of honour, which involves an abiding commitment to respect the group by behaving in accordance with its customs and norms (Welsh, 2008). Thus duty to codes represents a commitment to setting an example for honorable and praiseworthy behavior, not bringing shame or dishonor on oneself or an organization by doing what is wrong, and demonstrating personal integrity through strict adherence to an organization's codes. In sum, DO considers normative orientation impels individuals to think and act through the lens of their duties to serve organization's interests. Lastly, Iiu \& Tsaur (2014) has found that people who are positive emotions to their organization; agreeable; empathetic and need affiliation are more likely to engage in OCB. Based on results of literature review, this study expects that volitional orientation to support members and organization; exert more efforts to attain its mission and keep honorable behavior will promote OCB. Thus, the third hypothesis is formulated as follows:

Hypothesis 3: Public Banks' employees' DO positively influences on OCB.

\subsection{Mediating Role of DO}

A number of prior studies concluded that Employees' POS stimulates OCB (Chiang \& Hsieh, 2012; Shen et al., 2013; Çinar et al., 2013; Moon et al. 2013; Al-Homayan et al., 2013). Increasing OCB requires more DO (Hannah et al., 2014). Employees with high level of DO are willing to promote honourable behavior, have desire to attain organization's mission and objectives, they are strict adherence to an organization's codes and customs. Therefore, this study examines the mediating role of DO in the relationship between POS and OCB. Because past results referred to POS significantly affect DO and OCB and even propose that DO affects OCB, we expect that DO plays an intermediary role in the relationship between POS and OCB. Thus, the fourth hypothesis is formulated as follows:

Hypothesis 4: POS of Public Banks' employees enhances OCB through the mediating effect of DO.

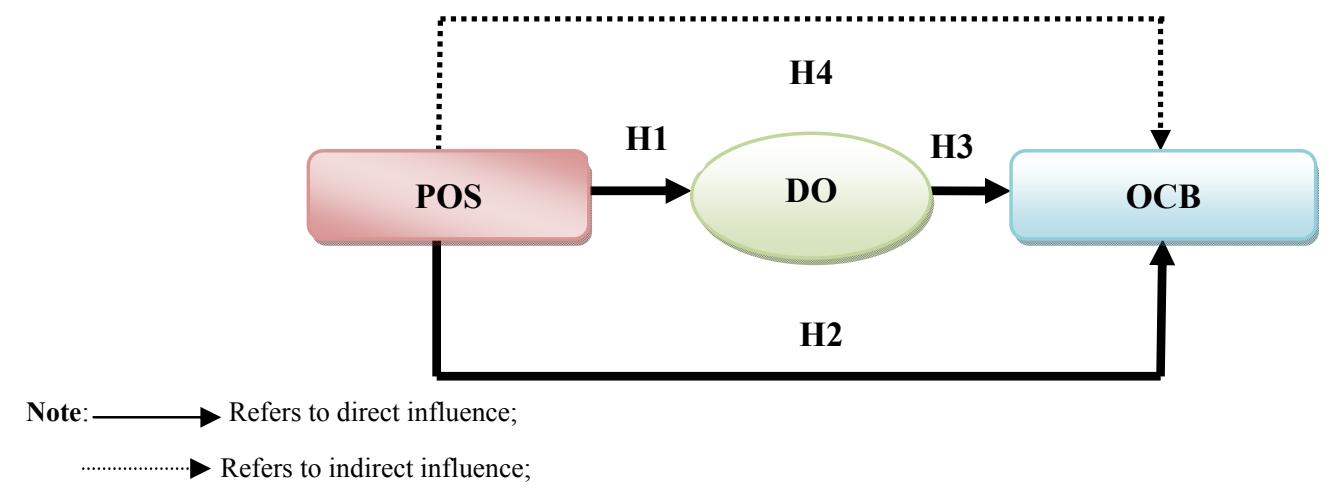

POS: Refers to perceived Organizational Support;

DO: Refers to Duty Orientation;

OCB: Refers to Organizational Citizenship Behavior.

Figure 1. Research model 


\section{Research Design}

This study examined the relationship between POS; DO; and OCB from the viewpoint of Public Banks' employees. Figure 1 shows research model that involves main variables of the study. Data is collected from 20 branches of four public banks (National Bank of Egypt; Bank Misr; Bank of Alexandria and Cairo Bank) working in Egypt through questionnaires with three sections: POS; DO; OCB; and basic respondent demographic characteristics. The study used Likert scale which consists of 5 points ranging from one (strongly disagree) to five (strongly agree).

The scale of the POS section consists of 10-items (e.g., "My bank strongly considers my goals and values."); this scale is based on Rhoades et al. (2001). But the scale of DO contains 12-items scale (e.g., "I Put the interests of my bank ahead of my personal interests.") this scale was adopted from Hannah et al. (2014). The last scale is OCB which was adopted from Podsakoff et al. (2000) with 28 items (e.g., "I am willing to help co-workers who have work related problems."). After developing research tool, draft questionnaire was reviewed by 10 researchers and public banks' managers. Then, a pilot study was conducted to insure that the draft of questionnaire is validated and reliable in collecting data, we distributed 175 questionnaires in the period between 10 June 2013 and 15 July 2013, only 120 were returned and the number of valid questionnaires was 105 for a response rate of $60 \%$. Some items were changed in wording according to pilot study' results in preparation for the final version questionnaire.

\section{Analysis and Results}

\subsection{Sample Structure}

The formal questionnaire was distributed randomly from August to October 2013. A total of 650 questionnaires were sent, including 425 by paper and 225 by email, we received 415 questionnaires. 12 invalid questionnaires were excluded, and then the number of valid questionnaires was 403 for a response rate of $62.0 \%$. As show in Table 1, most participants were males (70.72\%) and were aged between 36 and $45(47.15 \%)$, education levels were mostly college (77.42\%). All respondents had previous experience in the banking industry for more than two years and they were distributed all over departments in the bank. Researcher selected more respondents from young and middle-aged as they need more organizational support and duty orientation to motivate them to adopt organizational citizenship behaviors in public banks.

Table 1. Respondents' characteristics

\begin{tabular}{|c|c|c|}
\hline Characteristics & Sample $(N=403)$ & $(\%)$ \\
\hline Gender: & 403 & 100 \\
\hline Male & 285 & 70.72 \\
\hline Female & 118 & 29.28 \\
\hline Age & 403 & 100 \\
\hline $25-35$ years & 115 & 28.54 \\
\hline 36- 45 years & 190 & 47.15 \\
\hline 46- 55 years & 60 & 14.89 \\
\hline More than 55 & 38 & 9.42 \\
\hline Department: & 403 & 100 \\
\hline Front Office & 241 & 59.80 \\
\hline Back Office & 162 & 40.20 \\
\hline Education: & 403 & 100 \\
\hline Deplume & 85 & 21.09 \\
\hline Bachelor & 285 & 70.72 \\
\hline Post Graduate & 33 & 8.19 \\
\hline Experience: & 403 & 100 \\
\hline Less than 10 year & 135 & 33.50 \\
\hline 10- 20 years & 161 & 39.95 \\
\hline 20- 30 year & 63 & 15.63 \\
\hline More than 30 years & 44 & 10.92 \\
\hline
\end{tabular}




\subsection{Descriptive Analysis}

Table 2 illustrates that employees' perceptions about organizational support received from the bank was average (mean=3.15), this implying that employee perceived bank support and caring about their welfare as modest. On the other hand, bank' employees perceived that they had fair conformity with DO (Mean=3.96), this suggest that the level of DO was high between employees and their level of OCB was also high (Mean=4.02), this means that employees keen to help new co-workers in solving problems and adapting them with the bank's working environment; as well as willingness to do tasks of their co-worker when absent. The results refer to a positive and significant correlation between variables. The values of Cronbach's alpha ranged from 0.82 to 0.92 , this indicates to a good reliability.

Table 2. Descriptive analysis

\begin{tabular}{lccccc}
\hline Variables & $\begin{array}{c}\text { Mean (S.D.) } \\
(\mathbf{N}=\mathbf{4 0 3})\end{array}$ & $\begin{array}{c}\text { Cronbach's } \\
(\boldsymbol{\alpha})\end{array}$ & $\mathbf{1}$ & $\mathbf{2}$ & $\mathbf{3}$ \\
\hline 1. POS & $3.15(0.96)$ & 0.82 & 1 & & \\
2. DO & $3.96(0.78)$ & 0.86 & $0.57^{* *}$ & 1 & \\
3. OCB & $4.02(0.52)$ & 0.92 & $0.41^{*}$ & $0.46^{* *}$ & 1 \\
\hline
\end{tabular}

Note. ${ }^{*} p<0.05 ;{ }^{* *} p<0.01$.

\subsection{Results of Confirmatory Factor Analysis}

Confirmatory factor analysis (CFA) was used to examine the validity of the developed constructs, in which all measurement items were loaded on their expected constructs, and the constructs were correlated in the analysis. In the testing model for CFA, all factor loadings were significant $(p<0.001)$. The result of adaptability was $\chi^{2}=$ 1572.11; $d f=492 ; \chi^{2} / d f=3.20 ;$ RMSEA $=0.09 ; \mathrm{NFI}=0.80 ; \mathrm{NNFI}=0.83$ and CFI $=0.87$, this result was unsatisfactory according to fitness standards proposed by Hair et al. (2006) $\left[\chi^{2} / d f<3\right.$, RMSEA $\leq 0.08$, NFI $\geq$ 0.90$, NNFI $\geq 0.90, \mathrm{CFI}]$. Thus, the model needs some modification by removing items which have factor loading $<0.50$ and cross loadings (Bagozzi \& Yi, 1988). Modified testing model showed the following results: $\chi^{2}$ $=1253.62 ; \chi^{2} / d f=2.54 ; \mathrm{CFI}=0.97 ; \mathrm{NNFI}=0.96 ; \mathrm{NFI}=0.95$ and RMSEA $=0.06$, this result refers to acceptable standards for modified model. Table 3 shows that the composite reliability achieve high scores (ranged from 0.85 to 0.94 ) comparing with the standard (0.6). Each factor has high AVE (it ranged between 0.63 and 0.87 ) and was higher than the standard $(0.50)$. Additionally, the determination coefficient $\left(\mathrm{R}^{2}\right)$ of any two variables were less than the AVE; then, the measurement scale was acceptable and validity (Fornell \& Larcker, 1981).

Table 3. Results of confirmation factor analysis

\begin{tabular}{|c|c|c|c|c|}
\hline & Items & $\begin{array}{c}\text { Standardized } \\
\text { factor } \\
\text { loading }\end{array}$ & $\begin{array}{l}\text { Composite } \\
\text { reliability }\end{array}$ & $\begin{array}{c}\text { Average } \\
\text { variance } \\
\text { Extract } \\
\text { (AVE) }\end{array}$ \\
\hline (1) & Perceived organizational support (POS) & & 0.94 & 0.78 \\
\hline 1. & My bank cares about my opinions. & 0.83 & & \\
\hline 2. & My bank appreciates any extra effort from me. & 0.94 & & \\
\hline 3. & My bank really cares about my well-being. & 0.96 & & \\
\hline 4. & My bank cares about my general satisfaction at work. & 0.86 & & \\
\hline 5. & My bank strongly considers my goals and values. & 0.79 & & \\
\hline 6. & My bank takes pride in my accomplishments at work. & 0.75 & & \\
\hline 7. & My bank shows concern for me. & 0.91 & & \\
\hline 8. & Help is available from my bank when I have a problem. & 0.96 & & \\
\hline 9. & My bank would forgive an honest mistake on my part. & 0.81 & & \\
\hline 10. & My bank values my contribution to its well-being. & 0.85 & & \\
\hline (2) & Duty Orientation (DO) & & 0.86 & 0.67 \\
\hline \multicolumn{2}{|c|}{ Duty to members } & & 0.92 & 0.87 \\
\hline
\end{tabular}


1. I put the interests of my bank ahead of my personal interests.

0.84

0.96

2. I do all that I can to support the bank.

0.90

0.91

4. I am loyal to my bank and team.

1. I accept personal risk or loss in support of the mission/bank goals.

0.86

0.95

0.95

0.82

4. I get the job done under the toughest conditions.

\section{Duty to codes}

0.90

4. I set the example for honourable behavior for others in the bank.

(3) Organizational citizenship behavior (OCB)

Altruism

1. I help others who have heavy workloads in the bank.

2. I help others who have been absent in the bank.

3. I am willing to help others in the bank who have work related problems.

4. I help orient new people in the bank even though it is not required.

5. I am always ready to lend a helping hand to those around me in the bank.

\section{Courtesy}

1. I take steps to prevent problems for co-workers in the bank.

2. I consider the impact of my actions on co-workers in the bank.

3. I am mindful of my behavior affects other people's jobs in the bank.

4. I do not abuse or infringe on the rights of others in the bank.

5. I try to avoid creating problems for co-workers in the bank.

6. I am sensitive to the impact of my actions on my co-workers in the bank.

7. I show genuine concern and courtesy towards my co-workers in the bank.

\section{Civic virtue}

0.86

0.89

0.81

0.90

1. I attend meeting that are not mandatory, but are considered important for the bank.

2. I attend functions that are not required, but help the bank image.

3. I keep abreast of changes in the bank.

0.92

4. I attend training/information sessions that I am encouraged to in the bank.

5. I attend and actively participate in bank meetings.

6. I read and keep up with bank announcements, memos, and so on.

Sportsmanship

1. I consume a lot of time complaining about trivial matters in the bank (R).

0.78

5. I am the classic "squeaky wheel" in the bank that always needs greasing (R).

\section{Conscientiousness}

1. I obey bank's rules and regulations even when no one is watching.

3. I believe in giving an honest day's work for an honest day's pay in the bank.

4. My attendance at work is above the norm in the bank.

0.86

Note. (R) refers to reversed question items.

\subsection{Structural Equation Model (SEM)}

Structural equation model (SEM) was applied to test relationships between variables. The difference of $\chi^{2}\left(\Delta \chi^{2}\right)$ between the direct effects model and full mediation model is 186.85 as appeared in table 4 . At the same time, full mediation model had better fitness than the direct effects model according to indices GFI; CFI; NNFI and 
RMSEA. Next, we compared the partial mediation model with the full mediation model; the difference $\left(\Delta \chi^{2}\right)$ of $\chi^{2}$ is 43.03. So, the partial mediation model exceeds the Full mediation model, where fitness indices were $\chi^{2} / \mathrm{df}=$ 2.09; GFI $=0.93 ; \mathrm{CFI}=0.92 ; \mathrm{NNI}=0.92$ and $\mathrm{RMSEA}=0.04$. Then the model fitness was favourable, and congruence with the theoretical structure of the study.

Table 4. Fit indices of structural models

\begin{tabular}{lccccccc}
\hline \multicolumn{1}{c}{ Model type } & $\chi^{\mathbf{2}}$ & $\begin{array}{c}\chi^{2} / \mathbf{d f} \\
(<\mathbf{3})\end{array}$ & $\boldsymbol{\Delta} \chi^{2}$ & $\begin{array}{c}\text { GFI } \\
(>\mathbf{0 . 9 0})\end{array}$ & $\begin{array}{c}\text { CFI } \\
(>\mathbf{0 . 9 0})\end{array}$ & $\begin{array}{c}\text { NNFI } \\
(>\mathbf{0 . 9 0})\end{array}$ & $\begin{array}{c}\text { RMSEA } \\
(<\mathbf{0 . 0 8})\end{array}$ \\
\hline Direct Effects Model & $\begin{array}{c}1468.35^{*} \\
(\mathrm{df}=593)\end{array}$ & 2.48 & - & 0.83 & 0.92 & 0.90 & 0.07 \\
Full Mediation Model & $\begin{array}{c}1281.50^{* *} \\
(\mathrm{df}=592)\end{array}$ & 2.16 & 186.85 & 0.87 & 0.92 & 0.92 & 0.05 \\
Partial Mediation Model & $\begin{array}{l}1238.47^{* *} \\
(\mathrm{df}=590)\end{array}$ & 2.09 & 43.03 & 0.93 & 0.92 & 0.92 & 0.04 \\
\hline
\end{tabular}

Note. $\Delta \chi^{2}$ refers to difference between every two respectively models. ${ }^{*} p<0.05 ;{ }^{* *} p<0.01$.

In summary, results show that partial mediation model was favourable in this study. Table 5 indicates that bank employees' POS has significant and positive impact on their DO $(\beta=0.26, p<0.01)$, hence this result supports Hypothesis 1. POS also has significant and positive impact on their OCB $(\beta=0.19, p<0.05)$; so, the level of POS for employees in the bank has positive and significant impact on their OCB, this result validate Hypothesis 2. DO has significant and positive impact on $\operatorname{OCB}(\beta=0.34, \mathrm{p}<0.001)$, thereby proving and support Hypothesis 3. To examine whether DO was a mediating variable or not between POS and OCB; we used three- steps approach of Baron \& Kenny (1986) which measures: (1) the path regression between POS and OCB (this result must be significant); (2) the path regression between POS and DO, (this result must be significant too); (3) the path regression between POS and DO on OCB. If POS shows significance on DO, DO shows significance on OCB, and POS do not show significance on OCB, then DO is likely a full mediator. If POS still show significant impact on DO, but the path's coefficients is reduced, this indicates that DO is a partial mediator.

Table 5. Measuring the mediating role of DO

\begin{tabular}{cccc}
\hline & & \multicolumn{2}{c}{ Standardized path coefficients $(t$-value $)$} \\
\hline Model & $\begin{array}{c}\text { Direct Effects } \\
\text { Model }\end{array}$ & $\begin{array}{c}\text { Full Mediation } \\
\text { Model }\end{array}$ & $\begin{array}{c}\text { Partial Mediation } \\
\text { Model }\end{array}$ \\
\hline POS $\rightarrow$ OCB & $0.36\left(12.42^{* * *}\right)$ & & $0.19\left(2.68^{*}\right)$ \\
POS $\rightarrow$ DO & & $0.41\left(11.78^{* * *}\right)$ & $0.26\left(4.29^{* *}\right)$ \\
DO $\rightarrow$ OCB & & $0.46\left(8.31^{* * *}\right)$ & $0.34\left(5.16^{* * *}\right)$ \\
\hline
\end{tabular}

Note. ${ }^{*} \mathrm{P}<0.05 ;{ }^{* *} \mathrm{p}<0.01 ;{ }^{* * *} \mathrm{p}<0.001$.

According to the direct model in Table 5, POS has a distinct and significant path coefficient (POS $\rightarrow$ OCB: $\beta=$ $0.36, \mathrm{p}<0.001)$ on OCB of bank's employees, this result confirms the first step of Baron and Kenny's test. According to the full mediation model in table 5, POS has positive and significant impact on DO of bank's employees (POS $\rightarrow \mathrm{DO}: \beta=0.41, p<0.001$ ), as well as DO has positive and significant impact on OCB $(\mathrm{DO} \rightarrow \mathrm{OCB}: \beta=0.46, p<0.001)$, this result confirms the second step of Baron and Kenny's test. Lastly, according to the partial mediation model in table 5, employees' POS has a positive impact on their OCB ( $\beta=$ $0.19, \mathrm{p}<0.05)$. As POS and DO together positively influenced on employees' OCB $[(\mathrm{POS} \rightarrow \mathrm{DO}) \times(\mathrm{DO} \rightarrow \mathrm{OCB})$ $=0.26 \times 0.34=0.09)]$ and this coefficient is smaller than the coefficient of the impact of POS only on OCB $(0.19)$ as shown in figure 2. Therefore, this study found that DO plays a partial mediating role between POS and OCB. This result partially supports Hypothesis 4. We can summarize the hypothesis results in table 6. 


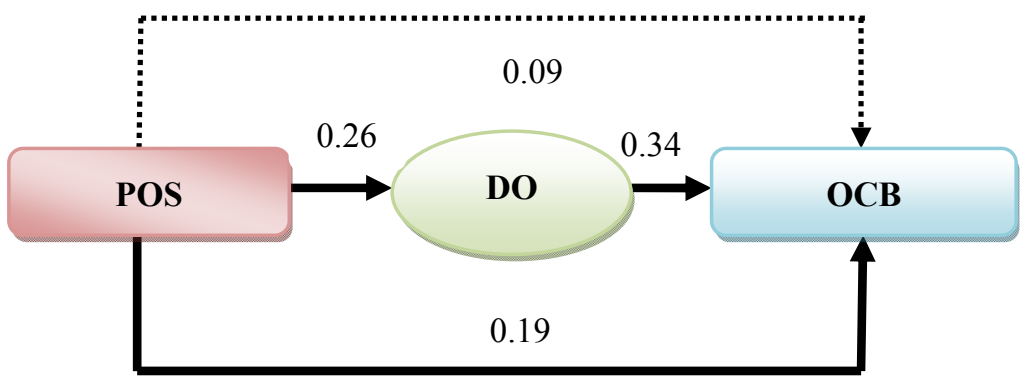

Figure 2. Results of partial mediation model

Table 6. Summary of hypothesis results

\begin{tabular}{lc}
\hline Hypothesis & Result \\
\hline H.1 Public banks' employees' POS positively influences on DO. & \\
H.2 Public banks' employees' POS positively influences on OCB. & Supported \\
H.3 Public banks' employees' DO positively influences on OCB. & Supported \\
H.4 POS of public banks' employees enhances OCB through the mediating effect of DO. & Supported \\
& Partially \\
& Supported \\
\hline
\end{tabular}

\section{Discussion}

\subsection{Employees' Perceptions of POS, DO and OCB}

At the first, results referred to the modest level POS of employees in the bank, where POS' average was 3.16 with standard deviation 0.96. This means that public banks could not introduce considerable support for their employees, this cause a sense of ignoring their effort and contribution to improve the bank's image among its customers. Additionally, employees in the public banks perceived that they receive modest care about their opinions from their banks; bank neutrally appreciates any extra effort from them and giving little care about their general satisfaction at work; lastly, the bank does not value their contributions to improve its reputation. This result inconsistent with the past findings which concluded that individuals perceived high level of organizational collaboration; so, they were psychologically encouraged towards exerting extra levels of effort, where POS leads to positive reactions such as increased OCB and decreased turnover intention (Shen et al., 2013; Epitropaki \& Martin, 2013; Islam et al., 2013).

On the other hand, employees agreed that they are duty oriented by the bank in fulfilling their tasks, where DO average was 3.96 with standard deviation 0.78 . This means that employees put the interests of the bank ahead of their personal interests and they perceive that their work is very important to them. So, they do all their best to support their bank and they get the job done under the toughest conditions associated working in banks. High level of DO means employees strive to be faithful and productive to the bank, conduct themselves in accordance with the bank's rules and regulations, and take on personal responsibility to uphold those rules and regulations as obligations. This result supported the findings of Garg \& Suri (2013) in their study on employees of public banking sector in India.

According to perceptions of OCB, most employees in the bank agree that they have a high level of OCB, where OCB average was 4.02 with standard deviation 0.52. Public banks' employees generally in Egypt consider themselves proactive in helping co-workers who have heavy workloads or who have been absent; they prevent problems and take into their consideration the impact of their actions on their co-workers; they attend meeting and assignments that are not mandatory but are considered important for the bank; they spend a little of time complaining about insignificant issues in the bank; lastly, they obey bank's rules in all times. Although POS in this study was modest, but the level of OCB was high among the bank's staff, this may due to the staff's commitment to the customs and religious traditions, which encourages them to work perfect and extend a helping hand to others at any time without waiting any formal reward. This study also confirmed with many past studies on OCB of employees in public banking sector (Garg \& Suri, 2013; Firozabad, 2013; Naderi \& Hoveida, 


\section{3; Iiu \& Tsaur, 2014).}

\subsection{Relationship between POS and DO}

This study suggests that bank's employees' POS has positive and significant effect on DO (Hypothesis 1). This means that employees with higher level of POS enjoy with high level of DO in the bank as follows: Firstly, they are duty for their banks by putting the interests of the bank ahead of their personal interests; they are faithful to their team members; they are loyal to their bank and team; and they do all their best to support their bank. This result supports the findings reported by Biswas \& Bhatnagar (2013) who suggested that when individuals perceive positive level of organizational support, they are psychologically committed to exert high levels of effort and time for improving organization's image. This commitment exists only due to the harmony between employees' personal values and those of their bank, which makes them feel with high duty to it. Paille \& Mejía-Morelos (2014) noted that POS has an indirect effect on pro-environmental behaviors through employee commitment to the organization. This suggests that when employees faced with ethical choices, employee with high level of DO will tend to engage higher levels of deonance. This high state of deonance limits an employee's perception of free choice in favour of fulfilling obligations. Additionally, Ahmed et al. (2010) asserted on when employees perceive high levels of organizational support, they would be more convinced that they have required resources enable them to do their tasks efficiently and they will reward for their efforts.

Secondly, when employees perceive high level of organizational support, they will have high duty to mission of the bank and they are prepare to accept personal risks or loss in support of its mission. In some cases, they make sacrifices to serve the mission of their bank and do whatever it takes to not let this mission fails even toughest conditions. According to social exchange theory, when employees perceive that bank cares their values and expectations, they will desire to act as ethically in the bank and this will creates a sense of duty. This normative of orientation is accompanied with a tendency to take actions that serve the good of the bank to fulfill its mission. Whereas banks frequently work in changing and complex environments, then success in accomplishing their tasks and missions in such contexts requires that all employees are oriented to take their responsibility and proactive that goes above and beyond minimum standards required by a duty of care. This result confirms also with the findings of Folger (2012, p. 125) who showed deonance counters another psychological force, reactance, defined as an orientation to resist any perceived reductions to, or elimination of, the freedom to choose any of the options available which may contradict with bank's mission in a given situation. So, higher level of duty to mission involves personal resolve to do whatever may be required to avoid the failure of tasks and missions and to make personal sacrifices and accept personal risks to fulfil bank's mission.

Thirdly, employees who perceive high level of organizational support have high duty to codes of the bank. They believe that they owed to the bank by serving its ethical codes reasonably, this requires doing right things always and demonstrate their personal integrity when challenge. Additionally, they will not accept dishonour actions at all, and they strive to set the example for honorable behaviors for others in the bank. This confirms with Welsh's result (2008) which asserts that duty to codes is closely associated with the notion of honour, which involves an abiding commitment to respect the group by behaving in accordance with its mores and norms. Thus, duty to codes would not only promote ethical acts, it will limit deviant acts that could shame or dishonour the bank, because of congruence between an ethical mindset of the employee and the bank. So, a broader range of behaviors may drive from strong DO than organizational values identification. This result agrees with Lord \& Brown (2004) who conclude to organizational values identification does not in itself refer to a sense of duty to behave in their service, because one may share the organization's values while being very discriminating about how he or she expresses those values across situations in the organization.

\subsection{Relationship between POS and $O C B$}

The results showed that employees who have high level of POS display high level of OCB; so, POS positively influence OCB (Hypothesis 2). Once the bank considers the needs and concerns of its employees, they will immediately feel and value this support. Accordingly, their attitudes toward the bank will change and become more positive, they are willing to spend more time and effort for improving bank's image from viewpoint of its customers, as well as motivating employees to help new co-workers or lending a helping hand to those around them in the bank (altruism); hesitating to abuse or infringe on the rights of others or show genuine concern and courtesy towards their co-workers in the bank (courtesy); keeping abreast of changes or attending and actively participate in bank meetings (civic virtue); always focus on what's right, rather than the negative side or rarely find mistake with what the bank is doing (sportsmanship); and lastly, they feel that they are conscientious employees or their attendance at work is above the norm in the bank (Conscientiousness). The study findings confirmed with previous research which concluded to when employees receive high POS, they will display high 
OCB (Chiang \& Hsieh, 2012; Naderi \& Hoveida, 2013).

\subsection{Relationship between $D O$ and $O C B$}

In the present study, the findings showed that DO has a significant and positive influence on OCB (Hypothesis 3). This means that employees with high level of DO more likely engagement with additional roles which beyond formal ones in the bank. This result showed that employees felt with high level of DO because of high duty to members in the bank; they have belief of their abilities to perform tasks with their existing skills; everyone have an option to initiate and adjust his or her actions; and lastly, they can influence on major outcomes at work in the bank. Accordingly, employees who have high level of DO showed more OCB, they exert extra time and effort in their jobs, help their co-workers, and kindly search better ways to do their jobs in the bank. They are taking initiative to help co-workers overcome problems; they are complying with banking rules and ethical codes, engaging extra roles aiming to help bank achieves its mission and goals; they are complying with banking regulations, adapting with unfavourable conditions without any complaint; they avoid to cause problems with co-workers, and they are continuing mindful and initiative when collaborating in banking activities. Additionally, high levels of DO among employees insure immediate response to customers' needs to increase banking service's effectiveness. This result confirms with prior studies which asserted on DO play an important role in motivating OCB (Hannah et al., 2014; Malik et al., 2013; Aksel et al., 2013).

\subsection{The Mediating Effects of DO}

The results showed that DO play partial mediating role between POS and OCB (Hypothesis 4); where employees' POS positively affect directly on employee OCB $(\beta=0.19, \mathrm{p}<0.05)$; at the same time POS positively influenced indirectly on employees' OCB through DO $(0.26 \times 0.34=0.09)$. The study confirmed the relationship between POS and DO; and when we examined the relationship between DO and OCB; the results revealed to employees' DO positively influenced OCB, this results confirmed with prior studies interested in POS; DO and OCB (Hannah et al., 2014; Chiang \& Hsieh, 2012; Naderi \& Hoveida, 2013; Malik et al., 2013; Aksel et al., 2013). Thus, to encourage OCB, banks must first care and appreciate any extra efforts from employees, because this will encourage them to show high levels of DO by better aligning employees with their duties in the bank. This result confirms with Hannah et al. arguments (2014) who concluded to increase followers' DO over time through leadership interventions. Then, induce employees' DO and ask about their suggestions and motivate them to develop all banking's services, this will encourage employees to solve customers' problems easier and cooperate with their co-workers more efficiently.

Hence, employees with high level of DO are motivated to display more OCB, because employee's decision to continue participating in the progress of the bank is based on the balance between the motives and benefits offered by the bank and contributions expected from the employee. So, an employee who possesses high level of DO toward his bank would tend to engage with high level of deonance when faced with ethical choices during practising his activities in the bank. This deonance balances against the countering force of reactance, the ability to consider and freely choose a wide set of possible courses of actions, including those that may conflict with the bank's codes. This result confirms with Folger et al.'s notion (2013) when they concluded to deonance limits free choice through inducing individual to act in ways that fulfil their duties to the group versus fulfilling self-interest or other possible motives.

\section{Conclusion and Managerial Implications}

\subsection{Conclusion}

This study aims to examine the mediating role of DO in the relationship between POS and OCB. The findings showed that DO serves as an important partial mediation mechanism in the relationship between POS and OCB. The findings also indicated that POS can foster DO, which leads to high level of OCB. Employees' POS also positively influenced DO and OCB; employees' DO positively influenced OCB. So, when banks introduce reasonable level of support for their employees and strive to satisfy their career aspirations, they will promote high level of DO between them. Thus, this strong DO provides the normative orientation for an employee to align his or her ethical choices and behaviors with the expectations and obligations of bank. So, managers must encourage employees to show high level of DO through introducing high level of POS to ensure achieving high level of OCB in public banks.

\subsection{Academic Contribution and Managerial Implications}

This study introduced a unique contribution when it examined the relationship between POS; DO and OCB simultaneously; using POS as independent variable, DO as partial mediator and OCB as dependent variable. This study introduced deep theoretical basis about the effect of POS on DO and OCB. The study suggested that 
managers should stimulate suggestions and new ideas from employees about job tasks, departmental issues, or banking policy. In sum, managers in banks should interact more with their employees, adopt their suggestions, and establish consistent relationships to make them feel duty orientation in their work. Additionally, the bank should redesign job tasks to stimulate duty orientation among their employees, when employees feel that they have duty to their members; to mission and to codes in their jobs and departments, they will have high levels of DO. So, managers should give employees reasonable organizational support to motivate them to be committed to accomplish the missions and objectives of the bank, in addition to solve customers and co-workers' problems immediately.

In their study, Beheshtifar \& Herat (2013) suggested that when employees feel supported, their outcomes towards organization are always positive which helps organization to achieve its goals. So, public banks' managers can use DO as a tool to maximize the effect of POS on OCB, especially in Muslim communities which replete with a high level of DO among its citizens. Finally, manager must exert a distinct effort to promote OCB between employees to achieve their career aspirations, because the results of recent studies concluded that OCB and trust are two influential antecedents of career success for Chinese people (Russo et al., 2014). Finally, promoting DO among employees can solve many problems associated with principals-agents relationships, because high employees' DO will psychologically obligated to limit self- serving and promote ethical behaviour.

\subsection{Research Limitations and Future Research Suggestions}

It should be noted that the current study has several limitations which provide opportunities for further research. The first limitation was selection of Egyptian public banks' employees as a research subject, thus the study results can only apply on these employees and cannot be extended to foreign or commercial banks working in Egypt. So, it is suggested to examine the level of DO in foreign or commercial banks and its influence on the relationship between POS they received and their intention to exert OCB. Another limitation of this study, this study examined variables as a total construct, so we need to examine interactive relationships between sub-dimensions of each variable and other variables' dimensions. Finally, by analyzing relationships between variables, we found a significant correlation between POS; DO; and OCB. However, this relationship needs further explanation in future studies especially in collective cultures' countries. Finally, DO still a new concept in organizational settings; so, it needs more study especially in its relation with ethical behaviour in organizations, because this will enable researchers to examine neglected psychological mechanisms linking leaders with followers`ethical behaviour.

\section{References}

Ahmed, A., Muhammad, U. R., Inam, U. H., Ahmed, J. F., Bilal, G. M., \& Umer, A. M. (2010). Perceived Organizational Support and Psychological Empowerment. European Journal of Social Sciences, 17(2), 186.

Aksel, I., Serinkan, C., Kiziloglu, M., \& Aksoy, B. (2013). Assessment of Teachers' Perceptions of Organizational Citizenship Behaviors and Psychological Empowerment: An Empirical Analysis in Turkey. Procedia-Social and Behavioral Sciences, 89, 69-73. http://dx.doi.org/10.1016/j.sbspro.2013.08.811

Al-Homayan, A. M., Shamsudin, F. M., Subramaniam, C., \& Islam, R. (2013). The Moderating Effects of Organizational Support on the Relationship between Job Stress and Nurses' Performance in Public Sector Hospitals in Saudi Arabia. Advances in Environmental Biology, 7(9), 2606-2617.

Alijanpour, M., Dousti, M., \& Khodayari, A. (2013). The relationship between the perceived organizational support and organizational commitment in staff (A case study: General office for sport and the youth, Mazandaran province). European Journal of Experimental Biology, 3(5), 165-171. Retrieved from http://ww.pelagiaresearchlibrary.com

Bagozzi, R., \& Yi, Y. (1988). On the evaluation of structural equation models. Journal of the Academy of Marketing Science, 16(1), 74-94. http://dx.doi.org/0092-0703/88/1601-0074

Baron, R. M., \& Kenny, D. A. (1986). The moderator-mediator variable distinction in social psychological research: conceptual, strategic and statistical considerations. Journal of Personality and Social Psychology, 51, 1173-1182. http://dx.doi.org/0022-3514/86/\$00.75

Beheshtifar, M., \& Herat, B. H. (2013). To Promote Employees Commitment via Perceived Organizational Support. International Journal of Academic Research in Business and Social Sciences, 3(1), 306-313.

Beheshtifar, M., Ali-Nezhad, H., \& Nekoie-Moghadam, M. (2012). Investigation of perceived organizational support on employees' positive attitudes toward work. Interdisciplinary Journal of Contemporary Research in Business, 4(8), 432-442. 
Biswas, S., \& Bhatnagar, J. (2013). Mediator Analysis of Employee Engagement: Role of Perceived Organizational Support, P-O Fit, Organizational Commitment and Job Satisfaction. VIKALPA, 38(1), $27-40$.

Bowra, Z. A., \& Naeem, M. (2013). Perceived Organizational Support and its Relationship with Institutional Commitment; Evidence from Higher Education Academic. Staff, Middle-East Journal of Scientific Research, 18(7), 942-949. http://dx.doi.org/10.5829/idosi.mejsr.2013.18.7.11799

Chiang, C. F., \& Hsieh, T. S. (2012). The impacts of perceived organizational support and psychological empowerment on job performance: The mediating effects of organizational citizenship behavior, International Journal of Hospitality Management, 31, 180-190. http://dx.doi.org/10.1016/j.ijhm.2011.04.011

Çinar, O., Karcioğlu, F., \& Alioğullari, Z. D. (2013). The relationship between organizational silence and organizational citizenship behavior: a survey study in the province of Erzurum, Turkey. Procedia-Social and Behavioral Sciences, 99, 314-321. http://dx.doi.org/10.1016/j.sbspro.2013.10.499

Epitropaki, O., \& Martin, R. (2013). Transformational-transactional leadership and upward influence: The role of Relative Leader-Member Exchanges (RLMX) and Perceived Organizational Support (POS). The Leadership Quarterly, 24, 299-315. http://dx.doi.org/10.1016/j.leaqua.2012.11.007

Farasat, E., \& Ziaaddini, M. (2013). Perceived Organizational Support and Deviant Behavior. Journal of Basic and Applied Scientific Research, 3(5), 517-528. Retrieved from http://www.textroad.com

Firozabad, M. M. (2013). The Mediating Effects of Psychological Empowerment and Job Satisfaction in the Relationship between Transformational Leadership and Organizational Citizen Behavior. Journal of Basic and Applied Scientific Research, 3(5), 237-244.

Folger, R. (2012). Deonance: Behavioral ethics and moral obligation. In D. De Cremer \& A. E. Tenbrunsel (Eds.), Behavioral business ethics, shaping an emerging field (pp. 121-139). New York: Routledge.

Folger, R., Ganegoda, D., Rice, D., Taylor, R., \& Wo, H. (2013). Bounded autonomy and behavioral ethics: Deonance and reactance as competing motives. Human Relations, 66, 905-924. http://dx.doi.org/10.1177/0018726713482013

Fornell, C., \& Larcker, D. F. (1981). Evaluating structural equation models with unobservable variables and measurement error. Journal of Marketing Research, 18(1), 39-50. Retrieved form http://Links.jstor.org/sici?sici=0022-2437\%28198102\%2918\%3A1\%3c39\%3AESEMWU\%3E2.0.CO\%3B $2-3$

Garg, A., \& Suri, S. (2013). Analyzing the impact of psychological empowerment on organizational citizenship behavior in public banking sector. International Journal of Marketing, Financial Services \& Management Research, 2(7), 80-94. Retrieved from http://www.indianresearchjournals.com

Ghasemizad, A., \& Mohammad, K. K. (2013). The Relationship between Perceived Organizational Support, Organizational Commitment, and Quality of Work Life and Productivity. Australian Journal of Basic and Applied Sciences, 7(8), 431-436.

Hair Jr., J. F., Black, W. C., Babin, B. J., Anderson, R. E., \& Tatham, R. L. (2006). Multivariate Data Analysis (6th ed.). Prentice Hall, Upper Saddle River, NJ.

Hakkak, M., \& Ghodsi, M. (2013). Investigating the Relation between Job satisfaction, Perceived Organizational Support and Organizational commitment. International Journal of Management and Humanity Sciences, 2(6), 513-520. Retrieved from http:// www.ijmhsjournal.com

Hannah, S. T., Jennings, P. L., Bluhm, D., Peng, P. C., \& Schaubroeck, J. M. (2014). Duty orientation: Theoretical development and preliminary construct testing. Organizational Behavior and Human Decision Processes, 123, 220-238. http://dx.doi.org/10.1016/j.obhdp.2013.10.007

Islam, T., Khan, S. R., Nourulkamar Bt, O., Ahmad, U., Ali, G., Ahmed, I., \& Bowra, Z. A. (2013). Turnover intentions: the influence of perceived organizational support and organizational commitment. Procedia-Social and Behavioral Sciences, 103, 1238-1242. http://dx.doi.org/10.1016/j.sbspro.2013.10.452

Khani, M. H., Fallah, M. Y., \& Ghasemi, H. (2013). The Relationship between Religiousness and Organizational Citizenship Behavior among the Teachers of Abeyek City (IRAN). Journal of American Science, 9(3), 304-310. 
Liu, J. S., \& Tsaur, S. H. (2014). We are in the same boat: Tourist citizenship behaviors. Tourism Management, 42, 88-100. http://dx.doi.org/10.1016/j.tourman.2013.11.001

Lord, R. G., \& Brown, D. J. (2004). Leadership processes and follower identity. Mahwah, NJ: Lawrence Erlbaum Associates.

Malik, F., Chugtai, S., Iqbal, Z., \& Ramzan, M. (2013). Does Psychological Empowerment Bring About Employee Commitment? Evidence from Telecommunication Sector of Pakistan. Journal of Business Studies Quarterly, 5(1), 14-21.

March, J. G., \& Weil, T. (2005). On leadership. Oxford, UK: Blackwell Publishers.

Moon, T. W., Hur, W. M., \& Jun, J. K. (2013). The role of perceived organizational support on emotional labor in the airline industry. International Journal of Contemporary Hospitality Management, 25(1), 105-123. Retrieved from http://www.internationalconference.com

Naderi, N., \& Hoveida, R. (2013). The relationship between Organizational Citizenship Behavior (OCB) and Human Resources Empowerment (HRE) Case study: University of Isfahan (Iran). International Journal of Human Resource Studies, 3(2), 69-78. http://dx.doi.org/10.5296/ijhrs.v3i2.3991

Nitesh, S., Nanda Kumar, V. M., \& Asok Kumar, S. (2013). Role of Pay as Perceived Organizational Support Contributes to Employee's Organizational Commitment: Case study. Advances in Management, 6(8), $52-54$.

Organ, D. W. (1988). Organizational Citizenship Behavior: the Good Soldier Syndrome. Lexington, MA: Lexington Books.

Paillé, P., \& Mejía-Morelos, J. H. (2014). Antecedents of pro-environmental behaviours at work: The moderating influence of psychological contract breach. Journal of Environmental Psychology, 38, 124-131. http://dx.doi.org/10.1016/j.jenvp.2014.01.004

Podsakoff, P. M., MacKenzie, S. B., Paine, J. B., \& Bachrach, D. G. (2000). Organizational citizenship behaviors: a critical review of the theoretical and empirical literature and suggestions for future research. Journal of Management, 26(3), 513-563.

Rhoades, L., \& Eisenberger, R. (2002). Perceived support: a review of the literature. Journal of Applied Psychology, 87, 698-714. http://dx.doi: 10.1037//0021-9010.87.4.698

Rhoades, L., Eisenberger, R., \& Armeli, S. (2001). Affective commitment to the organization: the contribution of perceived organizational support. Journal of Applied Psychology, 86(5), 825-836. http://dx.doi.org/10.1037//0021-9010.86.5.825

Russo, M., Guo, L., \& Baruch, Y. (2014). Work Attitudes, Career Success and Health: Evidence from China. Journal of Vocational Behavior. http://dx.doi:10.1016/j.jvb.2014.01.009.

Saufi, M. A., Kojuri, M. A., Badi, M., \& Agheshlouei, H. (2013). The impacts of organizational justice and psychological empowerment on organizational citizenship behavior: the mediating effect of job involvement. International Journal of Research in Organizational Behavior and Human Resource Management, 1(3), 116-135.

Scott, K. E. (1983). Corporation law and the American Law Institute corporate governance project. Stanford Law Review, 35, 927-948.

Shen, Y., Jackson, T., Ding, C., Yuan, D., Zhao, L., Dou, Y., \& Zhang, Q. (2013). Linking perceived organizational support with employee work outcomes in a Chinese context: Organizational identification as a mediator. European Management Journal. http://dx.doi.org/10.1016/j.emj.2013.08.004

Sherman, N. (1997). Making a necessity of virtue: Aristotle and Kant on virtue. Cambridge, UK: The Press Syndicate of the University of Cambridge.

Shusha, A. (2013). The Role of Psychological Engagement in Relationship between Perceived Organizational Support and Withdrawal Behavior and Intentions: An Empirical Study on Small Industries in Egypt. International Journal of Business and Management, 8(16), 22-29. http://dx.doi.org/10.5539/ijbm.v8n16p22

Trevino, L. K., Nieuwenboer, N. A. D., Kreiner, G. E., \& Bishop, D. G. (2014). Legitimating the legitimate: A grounded theory study of legitimacy work among Ethics and Compliance Officers. Organizational Behavior and Human Decision Processes, 123, 186-205. http://dx.doi.org/10.1016/j.obhdp.2013.10.009 
Tyler, T. R., \& Blader, S. L. (2000). Cooperation in groups: Procedural justice, social identity and behavioral engagement. Philadelphia: Psychology Press.

Wayne, S. J., Shore, L. M., \& Liden, R. C. (1997). Perceived organizational support and leader-member exchange: a social exchange perspective. The Academy of Management Journal, 40(1), 82-111.

Welsh, A. (2008). What is honor? A question of moral imperatives. Dexter, MI: Yale University Press.

Wren, T. E. (2010). Moral obligations: Action, intention and valuation (revised ed.). New Brunswick, NJ: Transaction Publishers.

Yen, C. H., \& Teng, H. Y. (2013). The effect of centralization on organizational citizenship behavior and deviant workplace behavior in the hospitality industry. Tourism Management, 36, 401-410. http://dx.doi.org/10.1016/j.tourman.2012.10.003

\section{Copyrights}

Copyright for this article is retained by the author(s), with first publication rights granted to the journal.

This is an open-access article distributed under the terms and conditions of the Creative Commons Attribution license (http://creativecommons.org/licenses/by/3.0/). 